\title{
Eosinophilic Esophagitis: Review and Update
}

\author{
Elisa Gomez Torrijos ${ }^{1 * t \neq}$, Rosario Gonzalez-Mendiola ${ }^{2 t \neq}$, Manuela Alvarado ${ }^{3 \dagger}$, \\ Robledo Avila ${ }^{4 t}$, Alicia Prieto-Garcia ${ }^{5 t}$, Teresa Valbuena ${ }^{6 t}$, Jesus Borja ${ }^{1+}$, \\ Sonsoles Infante ${ }^{5 t}$, M. Pilar Lopez ${ }^{7 \dagger}$, Eva Marchan ${ }^{8 t}$, Patricia Prieto ${ }^{9 t}$, Mar Moro ${ }^{10 t}$, \\ Ana Rosado ${ }^{10 \dagger}$, Vanessa Saiz ${ }^{11 \neq}$, M. Luisa Somoza ${ }^{12 \dagger}$, Olga Uriel ${ }^{13 t}$, Angelina Vazquez ${ }^{14 t}$, \\ Pilar Mur ${ }^{15}$, Paloma Poza-Guedes ${ }^{16 t}$ and Joan Bartra ${ }^{17 t \neq \hat{\$}}$
}

\section{OPEN ACCESS}

Edited by: Franco Scaldaferri, Università Cattolica del Sacro Cuore,

Italy

Reviewed by:

Giuseppe Losurdo,

University of Bari Medical School, Italy

Yuji Naito,

Kyoto Prefectural University of Medicine, Japan

*Correspondence:

Elisa Gomez Torrijos egomezt.cr@gmail.com

${ }^{\dagger}$ Food Allergy Committee (subcommittee of Esophagitis Eosinifilica) of the SEAIC (Sociedad Española de Alergia e Inmunologia Clínica)

FARADyAL Network. Instituto de Carlos III, Madrid, Spain

\$Institut d'Investigacions Biomediques August Pi I Sunyer (IDIBAPS)

Specialty section: This article was submitted to Gastroenterology, a section of the journal Frontiers in Medicine

Received: 05 June 2018 Accepted: 15 August 2018 Published: 09 October 2018

Citation:

Gomez Torrijos E

Gonzalez-Mendiola R, Alvarado M, Avila $R$, Prieto-Garcia A, Valbuena T, Borja J, Infante S, Lopez MP, Marchan E, Prieto P, Moro M, Rosado A, Saiz V, Somoza ML,

Uriel $O$, vazquez $A$, Mur $P$ Poza-Guedes P and Bartra J (2018) Eosinophilic Esophagitis: Review and

Update. Front. Med. 5:247

doi: 10.3389/fmed.2018.00247
${ }^{1}$ Hospital General Universitario de Ciudad Real, Ciudad Real, Spain, ${ }^{2}$ Hospital Central de la Cruz Roja San José y Santa Adela, Madrid, Spain, ${ }^{3}$ Hospital San Pedro de Alcántara, Cáceres, Spain, ${ }^{4}$ Hospital Universitario Virgen del Rocío, Seville, Spain, ${ }^{5}$ Hospital General Universitario Gregorio Marañón, Madrid, Spain, ${ }^{6}$ Hospital Infanta Sofía, Madrid, Spain, ${ }^{7}$ Hospital Clinico Universitario Virgen de la Arrixaca, Murcia, Spain, ${ }^{8}$ Hospital Virgen del Valle, Toledo, Spain, ${ }^{9}$ Hospital General Universitario de Albacete, Albacete, Spain, ${ }^{10}$ Hospital Universitario Fundación Alcorcón, Alcorcón, Spain, ${ }^{11}$ Hospital UniversitarioReina Sofía de Córdoba, Cordoba, Spain, ${ }^{12}$ Hospital Universitario Infanta Leonor, Madrid, Spain, ${ }^{13}$ Hospital Universitario de Araba, Vitoria-Gasteiz, Spain, ${ }^{14}$ Hospital Universitario Puerta de Hierro Majadahonda, Madrid, Spain,

${ }^{15}$ Hospital Santa Barbara, Puertollano, Spain, ${ }^{16}$ Allergy Section, Hospital Universitario de La Laguna, San Cristóbal de La Laguna, Spain, ${ }^{17}$ Allergy Section, Pneumology Department, Hospital Clínic Universitat de Barcelona, Barcelona, Spain

Background: Eosinophilic esophagitis (EoE) was first described in the 1990s, showing an increasing incidence and prevalence since then, being the leading cause of food impaction and the major cause of dysphagia. Probably, in a few years, EoE may no longer be considered a rare disease.

Methods: This article discusses new aspects of the pathogenesis, symptoms, diagnosis, and treatment of EoE according to the last published guidelines.

Results: The epidemiological studies indicate a multifactorial origin for EoE, where environmental and genetic factors take part. EoE affects both children and adults and it is frequently associated with atopic disease and IgE-mediated food allergies. In patients undergoing oral immunotherapy for desensitization from lgE-mediated food allergy the risk of developing EoE is $2.72 \%$. Barrier dysfunction and T-helper 2 inflammation is considered to be pathogenetically important factors. There are different patterns of clinical presentation varying with age and can be masked by adaptation habits. Besides, symptoms do not usually correlate with histologic disease activity. The diagnostic criteria for EoE has evolved but mainly requires symptoms of esophageal dysfunction with histologic evidence of a peak value of at least 15 eosinophils per high-power field. Endoscopies have to be repeated in order to diagnose, monitor, and treat EoE. Treatment of EoE can be started either by drugs (PPIs and topical corticosteroids) or elimination diets. The multistage step-up elimination diet management approach of EoE is promising. Endoscopic dilation is used for patients with severe dysphagia/food impaction with inadequate response to anti-inflammatory treatment.

Conclusions: Research in recent years has contributed to a better understanding of EoE's pathogenesis, genetic background, natural history, allergy workup, standardization in assessment of disease activity, evaluation of minimally invasive diagnostic tools, and new therapeutic approaches. However, several unmet needs are to be solved urgently, as 
finding a non-invasive disease-monitoring methods and biomarkers for routine practice, the development or new therapies, novel food allergy testing to detect triggering foods, drug, and doses required for initial therapy and safety issues with long-term maintenance therapy, amongst others. Besides, multidisciplinary management units of EoE, involving gastroenterologists, pediatricians, allergists, pathologists, dietitians, and ENT specialists are needed.

Keywords: eosinophilic esofagitis, esophagoscopy, eosinophilics, elimination diet, allergens

\section{INTRODUCTION}

There are no eosinophils in healthy esophageal mucosa. During the 1980s, some authors interpreted their presence in the esophageal mucosa as a histological marker of gastroesophageal reflux disease (GERD) (1, 2). Attwood et al. (3) in the USA (1993) and 1 year later Straumann et al. (4) in Switzerland defined eosinophilic esophagitis (EoE) as an entity with its own clinical and histological characteristics. Kelly et al. (5), in 1995, described a series of 23 children with GERD refractory to medical treatment and fundoplication, who responded to treatment with elemental diet. As a result, EoE was recognized as a form of food allergy. The first consensus guide of EoE (6) was published in 2007 and updated in 2011 (7). The American College of Gastroenterology in 2013 and the European and American Societies of Pediatric Gastroenterology (8) in 2014 published their guides for the management of EoE. Finally, the European guide on EoE has also edited some evidence-based statements and recommendations for diagnosis and treatment in children and in adults (9).

\section{DEFINITION}

Currently, EoE is defined as a chronic, local immune-mediated esophageal disease characterized, clinically, by symptoms related to esophageal dysfunction and, histologically, by eosinophilpredominant inflammation (9).

The disease is understood as a clinical-pathological entity, where symptoms and histology must always be considered together, both for the diagnosis and for the follow-up or assessment of the response to treatment $(7,10)$.

\section{EPIDEMIOLOGY}

In recent years, there has been an increase in the incidence and prevalence of EoE, with an exponential increase in articles published on EoE. In the USA and Europe, EoE is the most frequent cause of dysphagia in children and in young adults (11).

In children undergoing gastroscopy, irrespective of the cause, the prevalence was $3.7 \%$. When gastroscopy was due to impaction or dysphagia, the prevalence was higher: $63-88 \%$ in children $(12,13)$ and $10-15 \%$ in adults $(14)$.

In the general population, it is estimated to be about 30-52 cases per 100,000 inhabitants (15). A study conducted in central Spain between 2005 and 2011 (16) showed an average annual incidence of 6.37/100,000 inhabitants and a prevalence of
44.6/100,000 inhabitants, the latter being higher in urban areas (17).

Although EoE has been described in all races and continents, there is a slight predominance among Caucasians. It is more frequent in males than in females (3:1), this difference being more remarked (19:1) in a Spanish study (18). The mean age at the time of diagnosis ranges between $30-50$ years in adults (18) and 5.4-9.6 years in children (12).

Some groups have suggested a relationship between EoE and environmental exposure during the pollen season (19). However, a recent meta-analysis has concluded that no significant seasonal variation in the number of patients diagnosed nor in the number of episodes of food impaction that require medical assistance could be observed (20).

\section{ETIOPATHOGENESIS, PATHOPHYSIOLOGY, AND GENETICS}

Eosinophilic esophagitis is regarded as an esophageal inflammatory disease associated with atopic diseases. The genetic variation of thymic stromal lymphopoietin (TSLP) and calpain 14 (CAPN14) contributes to EoE, but the answer to how this relates to atopy remains unclear. Susceptibility to EoE is mediated by multiple genes, which have synergistic effects. These genes include those of general atopic disease and those specific to $\operatorname{EoE}(21)$.

Eosinophilic esophagitis is caused by an adaptive immune response to patient-specific antigens, primarily foods. Whether EoE is IgE-mediated or not is unknown. The most likely outcome is the presence of Th2 lymphocytes with an altered esophageal barrier function. The key cytokines and chemokines involved in the recruitment and remodeling of eosinophils are thymic stromal lymphopoietin, interleukin-13 (IL-13), CCL26/eotaxin3 , and transforming growth factor- $\beta$ (TGF- $\beta$ ). Chronic food dysphagia, food impaction, and the dreaded late complications are partly related to dense subepithelial fibrosis, probably induced by IL-13 and TGF- $\beta$ (22).

The deterioration of the epithelial barrier takes place because of genetic predisposition, reflux, and food intake. Invasive allergens and microbial antigens activate the innate and acquired immune systems. Eosinophils degranulate, release toxic proteins, and generate alterations in extracellular DNA, which serve as a defense system but also cause tissue damage. While releasing different cytokines, eosinophils modulate the inflammation and promote its chronification, finally resulting in fibrosis, which, in turn, has negative effects on the barrier function of the skin (23). 
The epidemiological studies carried out indicate a multifactorial origin for EoE, where environmental and genetic factors play a role (3). Epidemiological data support the predominance of the disease in men $(7,15,24)$ of white race $(25)$, as well as the family aggregation (26) observed in studies with families and in concordance studies between twins (27).

The hygiene hypothesis attributes the rise in EoE to modern hygienic conditions that have resulted in fewer childhood infections with microbes that might have protected against allergy development. Microbial dysbiosis, a change in the microbiome's composition and diversity caused by a modern affluent lifestyle, also might contribute to allergic conditions. Environmental factors that include modern chemicals contaminating crops, livestock treated with hormones and antibiotics, food additives and processing changes, and pollutants in the air and water conceivably might predispose people to EoE. An intriguing hypothesis attributes the increase in EoE to the increase in the use of acid-suppressive medications like proton pump inhibitors (PPIs), which might prevent peptic digestion of food allergens, increase gastric permeability, and alter the microbiome to favor food allergy development. In a recent pediatric case-control study, use of acid suppressants in infancy was by far the strongest risk factor identified for the development of EoE in the later stages of life (28). Specific Ig4 (sIgG4) antibiodies to cow's milk (CM) proteins are common, and a high titer of antibodies can be seen in children with EoE. Although it is unclear whether this response is pathogenic, sIgG4 levels imply that these antibodies are an important feature of the local immune response that gives rise to EoE (29).

A history of esophageal symptoms is found in $10 \%$ of the parents of these patients. In addition, if there is an affected sibling, the risk of suffering from a similar disease increases by $80 \%$.

Therefore, it is a complex disease, which does not follow the classic Mendelian pattern, producing interaction of multiple genes; some with a protective effect, others as a risk factor for the disease and whose expression could be conditioned by environmental factors (27).

1. The first genetic variant described was CCL26 (a gene encoding eotaxin 3 on chromosome 7q11) and its CCR3 receptor. The single nucleotide polymorphism (SNP) of CCL26 (rs2302009) is associated with the risk of suffering from the disease (30). Six years ago, they described polymorphisms in the promoter region of TGF- $\beta 1$ (chromosome 19q13). More than CC509T, the $\mathrm{C}$ allele is associated with a positive response to treatment with corticosteroids and with an increase in its expression in esophageal cells. The TT genotype could even be considered a pro-fibrosis risk factor. In children, a relationship has been found between the variants of the TGF$\beta 1$ gene and the degree of severity of EoE in patients sensitized to food (31).

The epidermal differentiation complex (EDC) binds a significant number of structuraly, functionally and evolutionarily related genes that play an important role in the terminal diferentiation of the hunman epidermis. It is located within the region q21 in the human chromosome 1 . The alterations that produce is what is known as the transcriptome of eosinophilic esophagitis. Whitin this chromosome are encoded several genes (fillaggrin, invlucrin, SSPRR family...) that intervene in the epithelial esophagus barrier. Therefore, the EDC is not a gene, it is a set of genes all od them encoded in human chromosome 1, in the 1q21 region (32). This set of alterations is known as the transcriptome of the EoE, which allows us to distinguish patients with EoE from healthy controls. Reversibility has been demonstrated after the remission of the disease following treatment with corticosteroids. Single nucleotide polymorphisms could be seen in the following cases.

Filaggrin (2288del4): whose loss of function is associated with alterations in the esophageal barrier, increasing permeability and susceptibility to allergens (32);

Desmoglein1 (transmembrane desmosomes): determines loss of barrier function and increases levels of IL-5 and TLSP;

Periostin (POSTN) (adhesion molecule that regulates the deposition of the extracellular matrix): an increase in its expression causes an increment in the process of esophageal remodeling.

\section{Genome-wide association studies (GWAS)}

They were first published in 2010. Single nucleotide polymorphism was found in the gene that codes for TSLP and WDR36 (chromosome 5q22) (33), whose expression increased in EoE.

Likewise, genes related to cellular autophagy (ATG7) are detected more frequently in active EoE, contrary to what occurs in EoE in remission, in GERD, or in normal subjects. So, it could be considered as a biomarker of EoE (34).

Recently, it has been investigated that the toll-like receptor 3 (TLR3) () constitutes a novel genetic susceptibility locus for developing EoE, and the effects would be independent of TSLP (35).

\section{EOSINOPHILIC ESOPHAGITIS, GASTROESOPHAGEAL REFLUX DISEASE, AND RESPONSE TO PROTON PUMP INHIBITORS}

During the 1980s, the presence of eosinophils in the esophageal mucosa was described in patients with $\operatorname{GERD}(1,2)$. Subsequently, EoE was identified as an entity with its own clinical and histological characteristics $(3,4)$. Both syndromes, GERD and EoE, can overlap and coexist in the same subject (36).

The clinical guidelines of EoE indicated that to reach the diagnosis of EoE, prior treatment with PPIs should be done at a double dose for 8 weeks to rule out $\operatorname{GERD}(7,8)$. Later, it was shown that omeprazole provides an anti-inflammatory effect independent of its anti-acid effect. As a result, the response to PPIs failed to differentiate patients with GERD from patients with EoE (37).

In the updated consensus of 2011, a group of patients with clinical characteristics of EoE and response to PPIs was recognized $(7,38)$. They were called PPI-responsive esophageal eosinophilia (PPI-REE) patients. Subsequent studies have shown 
that this group of patients did not differ from EoE patients, neither in the clinical, endoscopic, or histological characteristics nor in the expression of Th2 cytokines and their transcriptome (36, 38-45).

Secretion of Th2 cytokines can be inhibited by PPIs in a manner similar to corticosteroids in EoE (43). Thus, some experts regard that the treatment of EoE would start with PPIs, since they are safe drugs. In the case that eosinophilic inflammation subsided, we would be facing a PPI-REE. This name, according to experts, should be abandoned as it is an inadequate descriptor of this pathology $(46,47)$. The main novelty of the new guidelines on EoE (9) is the retraction of the term "PPI-REE," considering PPIs are at the same level as diets or topical steroids in the treatment of EoE and are not a diagnostic criteria anymore.

\section{Symptoms}

Symptoms in EoE are due to esophageal dysfunction, which can appear at any age. Nevertheless, it can be detected more frequently in children and in young adults until the 5th decade of life (18).

Some patients present symptoms constantly, others intermittently, remaining asymptomatic between periods of exacerbation (7). The symptoms can be present for a long time (mean of 3-5 years) before reaching a diagnosis of EoE in children and in adults, especially if the disease appears progressively $(7,48)$.

However, the diagnosis is not uncommon after a short history or even after an acute episode, mainly after an impaction (49). Clinical presentation varies according to age, evolving from nonspecific symptoms such as abdominal pain and rejection of food in pediatric patients to more pronounced esophageal symptoms such as dysphagia in adult patients (50).

In preschoolers, food refusal and intake of lesser amounts than those appropriate for their age are what we find more commonly. All of these along with vomiting, irritability, and abdominal pain will result in weight loss and failure to thrive.

In school children, food refusal, difficulties in introducing new foods in the diet, the preference for liquids and soft diets, and a tendency to be "slow eaters" are to be noted. In this group of children, abdominal pain and vomiting are the most frequent gastrointestinal symptoms.

In older children and adolescents, dysphagia and chocking are the most noteworthy symptoms. Impaction is more common in such cases than at early ages. They also maintain a preference for soft diets and fluid intake, tend to have a little varied diet, and may show fear and anxiety at the time of meals $(51,52)$.

Sometimes the first symptoms may be diarrhea and/or bloody stools, complicating early diagnosis (53). In many cases, children with EoE present vomiting and abdominal pain, which suggest gastroesophageal reflux disease. But in these cases, the symptoms are refractory to treatment (54).

In adults, dysphagia for solids and impaction of food $(50,55)$ are the principal symptoms. Chest pain can be associated with adults (50, 55-60). However, some of them only show symptoms of GERD or non-specific pharyngeal discomfort (59). Rarely, there could be spontaneous esophageal perforation due to intense vomiting (Boerhaave syndrome) after food impaction (56).
It has been postulated that these differences in the clinical presentation between pediatric and adult patients could conform to different causes; pediatric patients fail to express their symptoms in the same manner as adults, the time of evolution and the progression of the inflammatory disorder varies from an inflammatory phenotype in chilhood to a fibrostenotic one in adulthood (55).

The symptoms can also be masked, both in children and in adults, because along the years, the patients carry out dietary modifications to avoid the development of symptoms. This is why the medical history should include the following questions: "Do you chew your food a lot?" "Are you the last to get up from the table?" "Do you drink plenty of water during the meal to help you swallow?" "Do you avoid eating certain foods such as bread, rice, or meat?" "Do you cut the food into very small pieces?" $(56,61)$.

In conclusion, there are different patterns of clinical presentation varying with age, and they can be masked by adaptation habits $(56,61)$. In addition, the severity of the symptoms does not necessarily correlate with the density of the eosinophilic inflammation $(62,63)$. On the whole, symptoms alone are not enough to diagnose or to assess the response to treatment.

\section{Diagnosis}

The presence of the following diagnostic criteria is required for the diagnosis: (a) symptoms of esophageal dysfunction; (b) eosinophilic esophageal inflammation, with $\geq 15$ eosinophils per high-power field (eos/hpf), affecting the esophagus alone; and (c) excluding other causes of esophageal eosinophilia (Table 1) $(7,8)$.

Upper gastrointestinal endoscopy is the first diagnostic test to be performed when EoE is suspected. It includes the inspection of the esophagus, stomach, and duodenum, acquisition of esophageal biopsies of the previous places, and elimination of other pathologies (64). The endoscopic signs of EoE are shown in Table 2, Figure 1.

These endoscopic signs are neither pathognomonic of EoE nor are they enough to make diagnostic decisions (65). White exudates can be mistaken for candidiasic esophagitis and taking samples for fungal culture should be considered, mainly in patients treated with topical corticosteroids (TCs). Rings and stenosis are more common in adults than in children (57 and $25 \%$, respectively). Biopsies will always be performed, because

TABLE 1 | Other causes of esophageal eosinophilia.

Eosinophilic Gastroenteritis

Celíac Disease

Crohn's disease

Infection

Hypereosinophilic syndrome

Achalasia

Hypersensitivity to drugs

Vasculitis

Pemphigus

Connective tissue diseases 
up to $10 \%$ of the adult patients and $32 \%$ of the pediatric patients with a rigorously normal endoscopy pattern present esophageal eosinophilia (66). Recently, a grading system for the severity of endoscopic findings has been developed to evaluate the degree of disease activity (67). This proposed system for endoscopically-identified esophageal features of EoE defines common nomenclature and severity scores for the assessment of EoE disease activity. The system has good interobserver agreement among practicing and academic gastroenterologists (Table 3).

According to the histology of EoE, esophageal eosinophilia is irregular and variable between distal and proximal esophagus. Currently, the recommendation is to take at least six biopsies from two different sites, typically from the distal and proximal

TABLE 2 | Endoscopic findings in eosinophilic esophagitis.

\begin{tabular}{ll}
\hline Signs of inflammation & Signs of fibrostenosis \\
\hline Longitudinal furrows/ridges & $\begin{array}{l}\text { Fixed esophageal rings } \\
\text { "trachealization" } \\
\text { Exudates/White spots }\end{array}$ \\
$\begin{array}{l}\text { Feline esophagus } \\
\text { vale, edematous mucosa, decreased }\end{array}$ & $\begin{array}{l}\text { Esophageal rings or diffuse } \\
\text { esophageal stenosis, narrow caliber } \\
\text { esophagus }\end{array}$ \\
$\begin{array}{l}\text { Fragile mucosa, crêpe paper esophagus, } \\
\text { with lacerations at the passage of the } \\
\text { endoscope }\end{array}$
\end{tabular}

esophagus $(7,66)$. It is advisable to perform a biopsy for those areas with macroscopic inflammatory findings and for antrum and duodenum to rule out eosinophilic gastroenteritis (mainly in children and in adults with gastric or intestinal symptoms). In addition to the number of eosinophils, there are other histopathological findings associated with EoE that should also be reported (Table 4). Since symptoms do not correlate exactly with the activity of the disease, histology is still necessary to control the disease. In clinical practice, it is enough to perform haematoxylin-eosin staining for histological evaluation (9).

Lin et al. developed a new method for analysis and presentation of esophageal distensibility data using

TABLE 3 | Endoscopic scoring reference system to improve the reliability of endoscopic findings (67).

\footnotetext{
1) Major characteristics:

- Rings: (includes trachealization and transient rings)

Grade 0: none to Grade 3: severe (which do not allow the passage of the endoscope)

- Excluded (includes points and plates):

Grade 0: none to Grade 2: severe (more than 10\% of the esophageal surface)

- Edema (decreased vascularity):

Grade 0: absent to Grade 1: present

- Furrows: Grade 0: absent to Grade 1: present

- Stenosis or contractions: Grade 0: absent to Grade 1: present.

2) Minor features:

- Mucosa in "paper-crepe": Grade 0: absent to Grade 1: present.
}



FIGURE 1 | Endoscopic signs of the eosinophilic esophagitis. (A) longitudinal furrows, (B) Edema, (C) Exudate, (D) Pseudo rings, (F) Stenosis, (G) Fragility of the mucosa. (Images provided by the Multidisciplinary Group of Eosinophilic Esophagitis of the General University Hospital of Ciudad Real). 
TABLE 4 | Histological findings in eosinophilic esophagitis.

$\geq 15$ eosinophils per high-power field

Disposition of eosinophils in superficial layers of the epithelium

Disposition of eosinophils in accumulations or microabscesses

Extracellular eosinophilic granules

high-resolution impedance planimetry recordings during a volume-controlled distention. The results show that the patients with EoE and normal endoscopy had esophageal distensibility parameters similar to those of normal controls, whereas patients with EoE and stricture or narrow caliber had much lower distensibility than patients with EoE and normal endoscopy. The functional luminal imaging probe (FLIP) topography plots provided a global assessment of the esophageal distensibility along the axial plane of measurement that differentiated patients with varying degrees of endoscopic abnormality. So, new techniques can be leveraged to improve data analysis and presentation using EndoFLIP assessment of the esophageal body in EoE, since they may be helpful in defining phenotypes and guiding treatment strategies (68).

Allergological study is recommended yo every patient, since there is a strong association between EoE and atopy. On the one hand, about $50 \%$ of the patients present with peripheral blood eosinophilia. On the other hand, elevated levels of total Ig E can be detected in $80 \%$ of the patients. The association with rhinitis, asthma, eczema, or IgE-mediated food allergy is detected in 70, 40,30 , and $50 \%$ of the cases, respectively $(7,18)$. More than $80 \%$ of the patients have skin tests and/or IgE specific serum tests positive for inhalants or food. We can also find a profile of patients with negative allergy tests to all foods and who also respond to elimination diets.

Therefore, all patients require an evaluation by an allergist $(7,8)$, for the complete assessment of their allergic pathology as a whole. In addition, what is more important is that a correct interpretation of allergy tests is needed for avoiding unnecessary or undesirable food restrictions. The following analyses are recommended: hemogram (to detect peripheral blood eosinophilia) and general biochemistry including vitamins and micronutrients to assess the nutritional status. Skin prick test (SPT) should be performed with aeroallergens and with the group of six foods (milk, wheat, soybean/legumes, egg, peanut/nuts, and fish/shellfish) that are most frequently described as EoE-causing. Measures of total IgE and food specific IgE are also useful for the assessment of other associated pathologies, based on the clinical history of each patient.

Although SPT might be helpful in the design of elimination diets in about $50 \%$ of the patients, it is not enough to identify the offending foods that cause EoE.

The measurement of biomarkers in peripheral blood has not been helpful until now. Total IgE, eosinophil cationic protein (ECP), eosinophil-derived neurotoxin, tryptase, numerous cytokines, and a fraction of exhaled nitric oxide have been studied (69-71). Only peripheral blood eosinophils have proven to have a significant correlation with the degree of esophageal eosinophilia and its descent, after treatment with corticosteroids or PPIs, though their accuracy for diagnosis and their evaluation of disease activity are suboptimal (9).

The leukotriene C4 (LTC4) S mRNA and TSLP mRNA are elevated in a subgroup of the patients, and this could help in the differentiation between patients with EoE and an allergic-type phenotype (65).

Minimally invasive diagnostic tests such as esophageal string test and cytosponge have indicated good preliminary correlation with the degree of esophageal eosinophilia and eosinophilic derived proteins, but these data should be corroborated with larger studies $(9,72)$.

Recently, several promising minimally invasive biomarkers for EoE have emerged; however, only few of these are able to distinguish EoE from other atopic diseases (73).

\section{EOSINOPHILIC ESOPHAGITIS AND IGE-MEDIATED ALLERGY}

Patients with EoE usually suffer from a high number of concomitant atopic disorders that include rhinitis, asthma, and eczema. Besides, IgE-mediated food allergies are common in EoE patients.

The risk of developing EoE in patients undergoing oral immunotherapy for desensitization from IgE-mediated food allergy is $2.72 \%$ (74). There are cases described in the literature where patients showing allergic reactions to peanut (75), milk $(76,77)$, and egg $(78,79)$ develop EoE.

There are cases of patients who developed EoE after being treated with sublingual immunotherapy with pollen and mites that remitted with the withdrawal of immunotherapy $(80,81)$.

An occupational aeroallergen can also trigger EoE. There are two cases described. A female cook with bird-egg syndrome and occupational asthma due to egg manipulation developed EoE. The patient suffered an EoE reactivation when she ate poultry meat and by inhalation when she handled egg yolk (82). The other patient was a female baker who developed asthma and EoE by inhalation after exposure to wheat flour, but she was tolerant to wheat when exposed via the digestive route (83).

\section{EOSINOPHILIC ESOPHAGITIS: DIFFERENTIAL DIAGNOSIS}

Esophageal eosinophilia is not an exclusively anatomopathological finding of EoE. Therefore, a differential diagnosis must be made with respect to other digestive and extradigestive pathologies (Table 1) (8).

According to the latest guidelines (9), GERD and PPI-REE (currently PPI-responsive EE) are no longer considered in the differential diagnosis. Eosinophilic esophagitis and GERD can coexist in the same patient; therefore, they are not exclusive pathologies. In addition, PPI-REE (responsive EoE) and EoE have similar phenotypic, molecular, and pathophysiological characteristics and response to the treatment. With regard to this, they are not classified as different pathologies. The response to PPIs is not used for differential diagnosis but rather as a treatment for $\operatorname{EoE}(84,85)$ (Figure 2). 




FIGURE 2 | Therapeutic algorithm for EoE in clinical practice. Lucendo et al. (9). *In patients with persistent symptoms under anti-inflammatory therapy, endoscopic dilation should be considered. ${ }^{* *}$ Refer the patient to an EoE center.

\section{NATURAL HISTORY AND PROGNOSIS}

In EoE, the risk of developing esophageal stenosis increases with age and the delay in diagnosis and treatment $(48,86-88)$. Two of the most relevant studies on the progression of EoE in adults were conducted in a single center in Switzerland, where they demonstrated the persistence of dysphagia and eosinophilic inflammation, mainly in children, evolving into subepithelial fibrosis in adults $(89,90)$. Clinically and histologically active EoE must be treated. An EoE therapy should achieve two therapeutic goals: the first goal is to resolve symptoms and to improve, therefore, the quality of life; and the second goal is to control inflammation, so as to prevent esophageal damage caused by tissue remodeling. For children, the primary goal is to ensure normal growth and development.

Eosinophilic esophagitis is a chronic disease; as such, a longterm follow-up and therapeutic strategy is needed. An analogy of EoE has been made with bronchial asthma, since both are chronic pathologies and include tissue remodeling associated with Th2 cells.

Eosinophilic esophagitis is not life threatening; nevertheless, if left untreated it may cause permanent damage to the esophagus. However, as a chronic disease, the quality of life is substantially impaired as long as EoE is not properly treated. In children (7), modifications of eating habits to avoid dysphagia (see Diagnosis) also affect their social and psychological behavior (anxiety, depression, school problems, etc). The most frequent complications are as follows: esophageal stenosis, feeding impaction, esophageal perforation, and malnutrition. There is no evidence that EoE is a premalignant condition. No case of progression toward esophageal carcinoma or hypereosinophilic syndrome has been described. Nevertheless, an association between EoE and granular cell esophageal tumors has been reported recently (91).

In conclusion, there is an increasing incidence and prevalence of EoE. The considerable delay between symptom onset and diagnosis suggests that there are still clinicians who fail to recognize the disease, which may have important clinical implications (92).

\section{Treatment}

The three basic pillars in the treatment of EoE are as follows: drugs, elimination diets, and endoscopic dilation. The first two act on inflammation, and the third one acts on established fibrosis.

Treatment of EoE could be started by any one of the two options, either drugs or elimination diets. The first step in the treatment could be constituted by PPIs as these drugs are quite safe. In patients who fail to respond to PPIs, the second step could be elimination diets or TCs. Treatment must be individualized according to each patient or their family concerns and lifestyles, and it might be interchangeable over time (46).

The long-term therapeutic strategies and best maintenance doses for pharmacological therapies are not well-defined yet. 
TABLE 5 | Drugs used in the treatment of eosinophilic esophagitis.

\begin{tabular}{l} 
- Proton-pump inhibitor \\
Omeprazole and Esomeprazole* \\
- Children from 10 to $20 \mathrm{~kg}: 10 \mathrm{mg}$ twice a day \\
- Children > $20 \mathrm{~kg}: 20 \mathrm{mg}$ twice a day \\
- Adults: $40 \mathrm{mg}$ twice a day Initial dose 8 weeks. After minimum effective \\
maintenance dose \\
* It should not be used in children under 12 years of age \\
Swallowed topical corticosteroids \\
Fluticasone \\
- Children: 88 to $440 \mu \mathrm{g}$ twice a day \\
- Adults: 440 to $880 \mu \mathrm{g}$ twice a day Budesonide \\
- Maintenance: minimum effective dose \\
- Children: 0.5 mg twice a day \\
- Adults: 1 mg twice a day \\
- Maintenance: minimum effective dose \\
Oral corticosteroids \\
- Only in serious cases: Prednisone $1-2 \mathrm{mg} / \mathrm{kg} / \mathrm{day}$ \\
\hline
\end{tabular}

A reasonable approach is to decrease the dose to the lowest level that maintains the clinical and histological remission until more data are available.

\section{A) Pharmacological treatment (Table 5)}

A-1) Proton pump inhibitors: a recent systematic review with meta-analysis detected that they induce histological remission in at least $50 \%$ of the patients and clinical remission in an even higher percentage of patients $(50,93)$. The reason why some patients are responders and others are not has to be investigated.

In a retrospective study in adults and a prospective study in children, with a follow-up meta-analysis of 73 and $78.6 \%$ of the patients, respectively, the adults and children maintained remission with a minimum dose of PPI $(94,95)$. Patients with reactivation obtained remission by increasing the dose of IBPs to twice daily.

After achieving a remission, the patient should be put on the lowest PPI dose for maintenance treatment (Figure 2).

A-2) Topical corticosteroids: several randomized studies have shown the efficacy of TCs against placebo, improving symptoms and reducing eosinophilic esophageal inflammation. There are different percentages of response depending on the drug, dose, or formulation used $(63,96-101)$. Eosinophilic inflammation recurs when treatment is withdrawn $(7,8,102)$. There is no formulation that has been specifically approved for EoE, hence devices designed for asthma or rhinitis are used. Topical corticosteroids have to be swallowed twice daily and the patient should not eat or drink for the next 30-60 min.

The most commonly used TCs are fluticasone propionate and budesonide. They can be sprayed using a metered dose inhaler (MDI) device and then swallowed $(96,103)$; a liquid formulation for intranasal administration or nebulization and a viscous oral suspension prepared with sucralose that can be swallowed directly are also available (100). Moreover, ciclesonide sprayed with MDI and swallowed has been successfully administered $(104,105)$ in a small series of pediatric cases showing a low systemic bioavailability and a good safety profile.

Viscous oral administration of budesonide (64, 106-108) achieves higher histological remission rates than when it is sprayed and swallowed, owing to a longer contact time with the esophageal mucosa. High doses of fluticasone have recently demonstrated better response rates in children and in adults (103).

About $25-40 \%$ of the patients treated with TCs fail to achieve histological remission. Nevertheless, there are promising preliminary data with new formulations of budesonide (viscous solution, effervescent tablets) specifically designed for EoE. They achieved $100 \%$ remission in just 2 weeks of treatment (108).

Predictors of response to corticosteroids are poorly understood $(109,110)$. Recent genomic analysis will probably help us in the identification of patients with better likelihood for treatment response.

We know about the safety of short-term TCs in EoE, but there are a few studies that discuss the long-term safety as well. Oropharyngeal cavity and esophageal candidiasis may occur in $10 \%$ of the treated patients, being usually asymptomatic $(98,104)$. Other studies indicate the possibility of suppression of the adrenal axis $(111,112)$. Cortisol monitoring to prevent adrenal insufficiency could be advisable for children receiving high doses of swallowed TCs for long periods or concomitant use of inhaled/nasal corticosteroids for associated atopic diseases.

The optimal long-term maintenance dose of TCs is yet to be determined. The maintenance treatment is recommended with the minimum effective dose to maintain clinical and histological remission $(90,113)$. The main drawback of corticosteroid treatment is that almost all patients relapse rapidly after cessation of therapy. Therefore, they are able to control the disease but not cure it.

A-2.1) Systemic corticosteroids: their efficacy is similar to that of swallowed corticosteroids, but the risks of side effects are higher. Their use is restricted to emergency situations with severe dysphagia or significant weight loss $(7,8,102,114,115)$.

B) Elimination diet

The goal of dietary treatment strategies is to induce remission of EoE and, subsequently, help in the identification of food triggers, so as to avoid them and remain asymptomatic without the need for drugs.

Three possible strategies for dietary treatment have been described: elemental diets (ED), allergy testing-based elimination diets (ATBD), and empiric elimination of common dietary antigens that includes six-food elimination diet (SFED), fourfood elimination diet (FFED), or two-food elimination diet (TFED) (116).

To evaluate the patient's response to an elimination diet, clinical, and histological remission must be achieved, and the only way to know this is by performing endoscopy with biopsy: firstly after eliminating and secondly after reintroducing the offending food (8). The initial elimination diet will be established for 6 weeks. If remission is achieved, the sequential reintroduction of the eliminated foods (one group every 6 weeks) is carried out, with clinical and histological controls for each group. The food identified as responsible for causing EoE will be eliminated from the diet permanently. This process involves performing multiple endoscopies, which is cumbersome, and the overall uptake amongst clinicians is unknown and should be limited because of the high costs and safety concerns as 
well as the associated inconvenience for the patient, particularly children. Patient's acceptance of this strategy improves if sedation is provided during the endoscopy and if they are performed in well-defined time frames after reintroduction of the food, avoiding dietary restrictions for a longer time than necessary (117). This is, obviously, necessary in children, in which case repeated deep sedation with propofol has been demonstrated to be safe (118).

To carry out an elimination diet, joint assessment with a nutritionist is mandatory to ensure an adequate caloric, electrolyte, and micronutrient intake (119), and it also helps in the assessment of dietary compliance in the patient. A multidisciplinary team is required, including an allergologist, for interpreting food labels, identifying possible sources of contamination with hidden allergens, and avoiding crossreactivity of foods. The order of reintroduction of food can be adapted to the nutritional requirements or personal preferences of each patient.

B-1) Elemental diet

Elemental formulas based on essential amino acids lack proteins, thus, any allergenic source of the diet is eliminated. The carbohydrates and fats necessary to cover the daily dietary requirements are also added.

The initial efficacy data (120) have subsequently been supported by a long series of pediatric cases and adults, displaying remission results that exceed 90\% (121-125). Despite its high efficacy, the application of elemental diet in clinical practice is very limited because of its high cost (and it not being universally covered by health insurances), poor palatability, lack of adherence, and the need for nasogastric tubes in most of the children. In addition, the process of reintroduction of food is longer and, therefore, requires a greater number of endoscopies. The elemental formulas can be used as a nutritional supplement in other types of diets (119).

B-2) Allergy testing-based food elimination diet (ATBD)

Spergel et al. (126) using a combination of prick test and atopy patch tests in children, described an efficacy of about $75 \%$ in the elimination diet based on the positive results obtained from these tests $(126,127)$. These results, that were methodologically incorrect, could not be reproduced later $(123,128-131)$. After 10 years, the same group published a broader series of studies with a remission rate of $53 \%$ (124). It is important to point out that food patch tests are not standardized. The same authors propose to include the elimination of milk, since this food gives a low negative predictive value (NPV) in the skin tests (124). A recent meta-analysis revealed that this dietary approach led to histologic remission of $45.5 \%$ (132), when compared with the $72 \%$ observed with SFED and the $90.8 \%$ with elemental diet.

A diet based study on the elimination of foods demonstrated an $\operatorname{sIgE}$ value $\geq 0.1 \mathrm{kU} / \mathrm{L}$ and showed clinical-histological remission in $73 \%$ of the patients with fewer endoscopies than the SFED group. This study comprised of sIgE analysis for the six foods included in the group of SFED, and patients with negative sIgE were selected for the SFED (133). The elimination diet guided by blood IgE microarrays (component-resolved allergy diagnosis) has not been demonstrated to be effective as it had poor efficacy (7\% histologic remission) (134).

\section{B-3) Six-food group elimination diet (SFED)}

The empirical elimination of the six-food group most commonly associated with food allergy (milk, wheat, soybean/legumes, egg, peanut/nuts, and fish/shellfish) achieved clinical-histological response in $72 \%$ of the patients. It has been proven to be highly reproducible in various studies in children and in adults (132, 135-138).

Milk and wheat are identified as the most common causes of EoE, followed by eggs and legumes/soybeans.

In a follow-up study after 1 year and 3 years, respectively, there was no clinical-pathological recurrence if the elimination of the identified foods was maintained $(135,139)$. A Spanish study (60) identified a single causative food in $71 \%$ of the adult patients (133). In another study series including North American children, it was $72 \%$ (139). The existence of several causative foods for a long-term avoidance diet complicates compliance. The differences detected in the causative food may be because of dietary habits and specific sensitization patterns in different geographical areas (140). Therefore, the elimination diets should be adapted to each country or region.

Several studies have analyzed less strict elimination diets, easier to comply, with reduced number of endoscopic procedures and shortened diagnostic process time.

Thus, the empiric FFED (milk, wheat, egg, and legumes including soy) proved its effectiveness in two prospective studies: the first in 54\% of a group of adult Spanish patients (141) and the second in $64 \%$ of a group of children from the US (142). It consisted of eliminating, at first, the two most common food triggers (milk and cereals with gluten) and then increasing the level of restriction in non-responders.

Since milk is the most common food trigger in EoE, $\mathrm{CM}$ elimination diet has been proposed, achieving histological remission in $64 \%$ of children $(143,144)$. An extensive hydrolyzed formula of CM proteins has been well-tolerated in $88 \%$ of the adult patients with EoE caused by milk (145) as well as homemade or purchased products cooked with milk such as bread, muffins, or cakes for at least 6 weeks (146). This variety of milk products may improve compliance, quality of life, and nutrition in these patients. However, in a study that is being carried out by our group, 5 patients with EoE due to milk were allowed to have baked milk in their diet, and 6 weeks later all of them relapsed (unpublished data).

In summary, PPIs, topical steroids, or elimination diets might be offered as first line therapy for EoE patients. The question of which therapy would be administered first should be individually discussed with each patient and their relatives, and this might be interchangeable over time depending on the evolution of the disease and the patient's preferences. The efficacy of the therapy should be confirmed after 6-12 weeks with a follow-up endoscopy.

Endoscopic dilation is used for patients with severe dysphagia/food impaction with inadequate response to antiinflammatory treatment. The complexity of EoE treatment regimens and frequent follow-ups require a multimodal, multidisciplinary management approach to optimize patient care (147).

C) Other treatments 
Other treatments are also used for allergic diseases. Drugs such as montelukast and sodium cromoglycate are not recommended for the treatment of EoE, since neither of them showed any effects on symptom relief or in histological findings (148).

Various monoclonal antibodies have been investigated with unsatisfactory results.

Anti IL-5: Reslizumab treatment was studied in comparison with placebo in a study with 226 pediatric patients. The active treatment reduced the eosinophil count in the esophageal biopsy without significant symptom improvement (149). Two randomized controlled trials with mepolizumab have been reported in children and in adults (150), which showed no histological remission or differences in symptoms when compared with placebo.

Anti-TNF: Infliximab failed to reduce esophageal inflammation or to dismiss symptoms in a pilot study with three EoE patients (151).

Anti IgE: Omalizumab failed to reduce EoE-attributed symptoms or tissue eosinophil counts (152). In an open, nonblinded study in 15 patients, symptoms improved, but esophageal eosinophilia persisted after 3 months of treatment in $33 \%$ of the cases (153). A double-blind, placebo-controlled trial showed similar efficacy with placebo (154).

Anti CRTH2: CRTH2 is a G protein-coupled receptor expressed in all the cells that are involved in Th2 inflammation. OC000459 acts as an oral bioavailable CRTH2 antagonist. In a randomized, double-blind, placebo-controlled study with 26 patients diagnosed with EoE (155), eosinophil counts in the esophagus were significantly reduced in $36 \%$ of the patients. At the same time, the clinical assessment improved significantly in the active group but not in the placebo one.

It is important to point out the importance of IL-4, IL-13, and their receptors in allergic diseases, with an emphasis on asthma, atopic dermatitis, and $\mathrm{EoE}$ (156). Therefore, the following agents are being investigated.

Anti IL-13: A recent trial with QAX576 (157) showed a tendency to improve symptoms with a reduction of eosinophil levels in the esophagus (60\% decrease vs. an increase of $23 \%$ with placebo).

Anti IL-4: A randomized controlled trial with dupilumab is ongoing in adults with moderate or severe active EoE (NCT02379052 www.clinicaltrials.gov) (158).

Anti TGF- $\beta$ : An open trial with losartan, an angiotensin II receptor blocker that inhibits TGF- $\beta 1$, is underway in patients with EoE (NCT0180816 www.clinicaltrials.gov) (158).

Eotaxin anti-CCR3 receptor: An oral CCR3 receptor blocker is currently under development (158).

Azathioprine: A series of studies conducted in three adults with severe and cortico-dependent EoE was published. After treatment with azathioprine, they showed a symptomatic and histological response, relapsing when treatment was interrupted. Possible side effects limited the use of this drug (159).

A better understanding of the phenotypes and endotypes of allergic diseases has resulted in rapid development of biologic medications that target multiple steps of the inflammatory pathways. All of the biologic medications currently approved and most of the biologic medications under development for allergic diseases have focused on the Th2 inflammatory pathway. The novel biologic therapies that have emerged over several years in the past have amazingly improved the management of patients with refractory allergic disease as well as with EoE (160).

D) Endoscopic dilation

Mechanical dilation of the esophagus is useful when there is an established subepithelial fibrosis that causes esophageal narrowing. The goal is to relieve dysphagia and to achieve an esophageal caliber suitable for the proper passage of food. This treatment is effective in $75 \%$ of the patients (71), since the symptoms improve immediately. However, it cannot be considered as a first-line treatment or as a monotherapy, as it has no effect on the underlying inflammatory process. It should be considered in patients with dysphagia or esophageal narrowing and in non-responders to antiinflammatory treatment. Esophageal dilation has always been associated with risks in EoE. However, two systematic reviews demonstrated that the risk of esophageal perforation occurred in less than $1 \%$ of the cases, which is similar to the risk involved in dilating esophageal stenosis caused by other etiologies (161, 162).

\section{CONCLUSION AND FUTURE PERSPECTIVES}

Eosinophilic esophagitis has been known as a distinct disease entity only for the past two decades, but the progress that has been made by stakeholders regarding the understanding of EoE's pathogenesis, genetic background, natural history, allergy workup, standardization in assessment of disease activity, evaluation of minimally invasive diagnostic tools, and new therapeutic approaches is enormous (163). The incidence and prevalence of EoE have also increased in the same way, being the leading cause of food impaction, the major cause of dysphagia, and accounting for high health-related costs. Therefore, in a few years, EoE may no longer be considered as a rare disease.

The main novelty of the new guidelines on EoE (9) is the retraction of the term "PPI-REE," not considering the response to PPIs as a diagnostic criterion anymore. In the treatment of EoE, PPIs are now at the same level as diets or topical steroids, and the choice of therapy should be individually discussed with the patients and relatives.

The multistage step-up elimination diet management approach of EoE is one of the most important solutions in the treatment of this disease (9), because its advantages may definitely help in the improvement of adherence to dietary therapy not only in EoE patients and their families but also in health professionals and caregivers.

Further studies are needed the development of birth cohort studies, non-invasive disease monitoring methods, biomarkers for routine practice, the development of new therapies, comprehensive standardized scoring systems for symptoms, 
quality of life, increase in awareness about EoE, novel food allergy testing to detect triggering foods in EoE and the implications of cross reactivity of food allergens, drug and doses required for initial therapy and safety issues with maintenance therapy (especially in children).

Multidisciplinary management of EoE, involving gastroenterologists, pediatricians, allergists, pathologists, dietitians, and ENT specialists, is required. The recent formation of the Consortium of Eosinophilic Gastrointestinal Disease

\section{REFERENCES}

1. Brown LF, Goldman H, Antonioli DA. Intraepithelial eosinophils in endoscopic biopsies of adults with reflux esophagitis. Am J Surg Pathol. (1984) 8:899-905. doi: 10.1097/00000478-19841200000002

2. Winter HS, Madara JL, Stafford RJ, Grand RJ, Quinlan JE, Goldman H. Intraepithelial eosinophils: a new diagnostic criterion for reflux esophagitis. Gastroenterology (1982)83:818-23.

3. Attwood SE, Smyrk TC, Demeester TR, Jones JB. Esophagealeosinophilia with dysphagia. A distinct clinicopathologic syndrome. Dig Dis Sci. (1993) 38:109-16.

4. Straumann A, Spichtin HP, Bernoulli R, Loosli J, Vogtlin J. Idiopathic eosinophilic esophagitis: a frequently overlooked disease with typical clinical aspects and discrete endoscopic findings. Schweiz Med Wochenschr. (1994) 124:1419-29.

5. Kelly KJ, Lazenby AJ, Rowe PC, Yardley JH, Perman JA, Sampson HA. Eosinophilic esophagitis attributed to gastroesophagealreflux: improvement with an amino acid-based formula. Gastroenterology (1995)109:1503-12.

6. Furuta GT, Liacouras CA, Collins MH, Gupta SK, Justinich C, Putnam PE, et al. Eosinophilic esophagitis in children and adults: asystematic review and consensus recommendations for diagnosis and treatment. Gastroenterology (2007) 133:1342-63. doi: 10.1053/i.gastro.2007.08.017

7. Liacouras CA, Furuta GT, Hirano I, Atkins D, Attwood SE, Bonis PA, et al. Eosinophilic esophagitis: updated consensus recommendations for children and adults. J Allergy Clin Immunol. (2011) 128:3-20. doi: 10.1016/j.jaci.2011.02.040

8. Dellon ES, Gonsalves N, Hirano I, Furuta GT, Liacouras CA, Katzka DA. ACG Clinical guideline: evidenced based approach to the diagnosis and management of esophageal eosinophilia and eosinophilic esophagitis (EoE). Am J Gastroenterol. Am J Gastroenterol. (2013) 108:679-92. doi: 10.1038/ajg.2013.71

9. Lucendo AJ, Molina-Infante J, Arias Á, von Arnim U, Bredenoord AJ, Bussmann C, et al. Guidelines on eosinophilic esophagitis: evidencebased statements and recommendations for diagnosis and management in children and adults. United Eur Gastroenterol J. (2017) 5:335-58. doi: $10.1177 / 2050640616689525$

10. Molina-Infante J, Lucendo J. Eosinophilic esophagitis: a practical approach to diagnosis and management. Expert Rev. Gastroenterol. Hepatol. (2014) 8:925-34. doi: 10.1586/17474124.2014.919851.

11. Straumann A, Schoepfer A. Update on basic and clinical aspects of eosinophilic oesophagitis. Gut (2014) 63:1355-63. doi: 10.1136/gutinl-2013-306414

12. Soon IS, Butzner JD, Kaplan GG, deBruyn JCC. Incidence and prevalence of eosinophilic esophagitis in children. Gastroenterology (2013) 57:72-80. doi: 10.1097/MPG.0b013e318291fee2

13. Hurtado CW, Furuta GT, Kramer RE. Etiology of esophageal food impactations in children. J Pediatr Gastroenterol Nutr. (2011) 52:43-6. doi: 10.1097/MPG.0b013e3181e67072

14. Mackenzie SH, Go M, Chadwick B, Thomas K, Fang J, Kuwada S, et al. Eosinophilic oesophagitis in patients presenting with dysphagiaa prospective asis. Aliment Pharmacol Ther. (2008) 28:1140-6. doi: $10.1111 /$ j.1365-2036.2008.03795.x
Researchers (part of the Rare Disease Clinical Research Network of the National Institutes of Health) and EoE Connect will help to improve the understanding and treatment of EoE (https://www. rarediseasesnetwork.org/cms/cegir/ and https://eoeconnect.eu/).

\section{AUTHOR CONTRIBUTIONS}

All authors listed have made a substantial, direct and intellectual contribution to the work, and approved it for publication.

15. Hruz P, Straumann A, Bussmann C, Heer P, Simon HU, Zwahlen M, et al. Escalating incidence of eosinophilic esophagitis: a 20 -year prospective, population-based study in Olten County, Switzerland. J Allergy Clin Immunol. (2011)128:1349-1350. doi: 10.1016/j.jaci.2011.09.013

16. Arias A, Lucendo AJ. Prevalence of eosinophilic oesophagitis in adult patients in a central region of Spain. Eur J Gastroenterol Hepatol. (2013) 25:208-12. doi: 10.1097/MEG.0b013e32835a4c95

17. Spergel JM, Book WM, Mays E, Song L, Shah SS, Talley NJ, Bonis PA. Variation in prevalence, diagnostic criteria, and initial management options for eosinophilic gastrointestinal diseases in the United States. J Pediatr Gastroenterol Nutr. (2011)52:300-6. doi: 10.1097/MPG.0b013e3181eb5a9f

18. Hruz P. Epidemiology of eosinophilic esophagitis. Dig Dis. (2014)32:40-47. doi: $10.1159 / 000357008$

19. Jensen ET, Shah ND, Hoffman K, Sonnenberg A, Genta RM, Dellon ES. Seasonal variation in detection of oesophageal eosinophilia and eosinophilic oesophagitis. Aliment Pharmacol Ther. (2015) 42:461-9. doi: 10.1111/apt.13273

20. Lucendo AJ, Arias Á, Redondo-González O, González-Cervera J. Seasonal distribution of initial diagnosis and clinical recrudescence of eosinophilic esophagitis: a systematic review and meta-analysis. Allergy (2015) 70:164050. doi: $10.1111 /$ all.12767

21. Martin LJ, He H, Collins MH, Abonia JP, Biagini Myers JM, Eby M, et al. EoE genetic susceptibility is mediated by synergistic interactions between EoEspecific and general atopic disease loci. J Allergy Clin Immunol. (2018). 141:1690-8. doi: 10.1016/j.jaci.2017.09.046

22. Clayton F, Peterson K. Eosinophilic esophagitis: pathophysiology and definition. Gastrointest Endosc Clin N Am. (2018) 28:1-14. doi: 10.1016/j.giec.2017.07.011

23. Straumann A, schoepfer AM, Simon HU. Current concepts in eosinophilic esophagitis. Allergo J Int. (2017) 26:258-66. doi: 10.1007/s40629-017-0037-8

24. Dellon ES, Jensen ET, Martin CF, Shaheen NJ, Kappelman MD. Prevalence of Eosinophilic Esophagitisin the United States. Clin Gastroenterol Hepatol. (2014) 12:589-96.e1. doi: 10.1016/j.cgh.2013.09.008

25. Dellon ES. Epidemiology of eosinophilic esophagitis. Gastroenterol Clin North Am. (2014) 43:201-18. doi: 10.1016/j.gtc.2014.02.002

26. Blanchard C, Rothenberg ME. Basic pathogenesis of eosinophilic esophagitis. Gastrointest Endosc Clin North Am. (2008) 18:133-43. doi: $10.1016 /$ j.giec.2007.09.016

27. Sleiman PM, March M, Hakonarson $\mathrm{H}$. The genetic basis of eosinophilic esophagitis. Best Pract Res Clin Gastroenterol. (2015) 29:701-7. doi: 10.1016/j.bpg.2015.09.003

28. Spechler SJ. Speculation as to why the frequency of eosinophilic esophagitis is increasing. Curr Gastroenterol Rep. (2018) 20:26. doi: $10.1007 / \mathrm{s} 11894-018-0633-\mathrm{x}$

29. Schuyler AJ, Wilson JM, Tripathi A, Commins SP, Ogbogu PU, Kruzsewski PG, et al. Specific IgG4 antibodies to cow's milk proteins in pediatric patients with eosinophilic esophagitis. J Allergy Clin Immunol. (2018) 142:13948.e12. doi: 10.1016/j.jaci.2018.02.049

30. Blanchard C, Wang N, Stringer KF, Mishra A, Fulkerson PC, Abonia JP, et al. Eotaxin-3 and a uniquely conservedgene-expression profile in eosinophilic esophagitis. J Clin Invest. (2006) 116:536-47. doi: 10.1172/JCI26679

31. Rawson R, Anilkuma A, Newbury RO, Bafna V, Aquino M, Palmquist J, et al. TGF $\beta 1$ promoter SNP C-509T and food sensitization promote 
esophageal remodeling in pediatric eosinophilic esophagitis. PLoS ONE (2015) 10:e0144651. doi: 10.1371/journal.pone.0144651

32. Blanchard C, Stucke EM, Burwinkel K, Cadwell JM, Collins MH, Ahrens A, et al. Coordinate interaction between Il-13 and epithelial differentiation cluster genes in eosinphilic esophagitis. J Immunol. (2010) 184:4033-41. doi: 10.4049/jimmunol.0903069

33. Rothenberg ME, Spergel JM, Sherrill JD, Annaiah K, Martin LJ, Cianferoni A et al. Common variants at $5 \mathrm{q} 22$ associate with pediatric eosinophilic esophagitis. Nat Genet. (2010) 42:289-91. doi: 10.1038/ng.547

34. Merves JF, Whelan KA, Benitez AJ, Muir AB, Furuta GT, Wang ML, et al. ATG7 gene expression as a novel tissue biomarker in eosinophilic esophagitis. Am J Gastroenterol. (2016) 111:151-3. doi: 10.1038/ajg.2015.404

35. Ávila-Castellano R, García-Lozano JR, Cimbollek S, Lucendo AJ, Bozada JM, Quiralte J. Genetic variations in the TLR3 locus are associated with eosinophilic esophagitis. United Eur Gastroenterol J. (2018) 6:349-57. doi: $10.1177 / 2050640617732643$

36. Kia L, Hirano I. Distinguishing GERD from eosinophilic esophagitis: concepts and controversies. Nat Rev Gastroenterol Hepatol. (2015) 12:37986. doi: $10.1038 /$ nrgastro.2015.75

37. Cheng E, Zang X, Huo X, Yu C, Zhang Q, Wang DH, et al. Omeprazole blocks eotaxin-3 expression by oesophageal squamous cells from patients with eosinophilic oesophagitis and GORD. Gut (2013) 62:82432. doi: 10.1136/gutjnl-2012-302250

38. Molina-Infante J, Ferrando-Lamana L, Ripoll C, Hernandez-Alonso M, Mateos JM, Fernandez-Bermejo M, et al. Esophageal eosinophilic infiltration responds to proton pump inhibition in most adults. Clin Gastroenterol Hepatol. (2011) 9:110-17. doi: 10.1016/j.cgh.2010.09.019

39. Warners MJ, van Rhijn BD, Curvers WL, Smout AJ, Bredenoord AJ. PPI-responsive esophageal eosinophilia cannot be distinguished from eosinophilic esophagitis by endoscopic signs. Eur J Gastroenterol Hepatol. (2015) 27:506-11. doi: 10.1097/MEG.0000000000000331

40. Dellon ES, Speck O, Woodward K, Gebhart JH, Madanick RD, Levinson S, et al. Clinical and endoscopic characteristics do not reliably differentiate PPIresponsive esophageal eosinophilia and eosinophilic esophagitis in patients undergoing upper endoscopy: a prospective cohort study. Am J Gastroenterol (2013) 108:1854-60. doi: 10.1038/ajg.2013.363

41. Collins MH. Histopathologic features of eosinophilic esophagitis and eosinophilic gastrointestinal di seases. Gastroenterol Clin North Am. (2014) 43:257-68. doi: 10.1016/j.gtc.2014.02.007

42. Moawad FJ, Schoepfer AM, Safroneeva E, Ally MR, Chen YJ, Maydonovitch $\mathrm{CL}$, et al. Eosinophilic oesophagitis and proton pump inhibitor-responsive oesophageal eosinophilia have similar clinical. Aliment Pharmacol Ther. (2014) 39:603-8. doi: 10.1111/apt.12636

43. Wen T, Stucke EM, Grotjan TM, Kemme KA, Abonia JP, Putnam PE, et al. Molecular diagnosis of eosinophilic esophagitis by gene expression profiling. Gastroenterology (2013) 145:1289-99. doi: 10.1053/j.gastro.2013.08.046

44. Molina-Infante J, Rivas MD, Hernandez-Alonso M, Vinagre-Rodriguez G, Mateos-Rodriguez JM, Dueñas-Sadornil C, et al. Remission in proton pump inhibitor-responsive esophageal eosinophilia correlates with down regulation of eotaxin-3 and TH2 cytokines, similarly to eosinophilic esophagitis after steroids. Aliment Pharmacol Ther. (2014) 40:955-65.

45. Wen T, Dellon ES, Moawad FJ, Furuta GT, Aceves SS, Rothenberg ME. Transcriptome analysis of proton pump inhibitor-responsive esophageal eosinophilia reveals proton pump inhibitor-reversible allergic inflammation. J Allergy Clin Immunol. (2015) 135:187-97. doi: 10.1016/j.jaci.2014. 08.043

46. González-Cervera J, Lucendo AJ. Eosinophilic esophagitis: an evidencebased approach to therapy. J Investig Allergol Clin Immunol. (2016) 26:8-18.

47. Molina-Infante J, Gonzalez-Cordero PL, Lucendo AJ. Proton pump inhibitorresponsive esophageal eosinophilia: still a valid diagnosis? Curr Opin Gastroenterol. (2017)33:285-92. doi: 10.1097/MOG.0000000000000371

48. Schoepfer AM, Safroneeva E, Bussmann C, Kuchen T, Portmann S, Simon HU, Straumann A. Delay in diagnosis of eosinophilic esophagitis increases risk for stricture formation in a time-dependent manner. Gastroenterology (2013)145:1230-6. doi: 10.1053/j.gastro.2013.08.015

49. Bystrom J, O'Shea NR. Eosinophilic oesophagitis: clinical presentation and pathogenesis. Postgrad Med J. (2014) 90:282-9. doi: 10.1136/postgradmedj-2012-131403
50. Miehlke S. Clinical features of eosinophilic esophagitis. Dig Dis. (2014) 32:61-7. doi: 10.1159/000357011

51. Menard-Katcher C, Henry M, Furuta GT, Atkins D, Maune NC, Haas AM. Significance of feeding dysfunction in eosinophilic esophagitis. World J Gastroenterol. (2014) 20:11019-22. doi: 10.3748/wjg.v20.i31. 11019

52. Papadopoulou A and Amil Dias J. Eosinophilic esophagitis: an emerging disease in childhood-review of diagnostic and management strategies. Front Pediatr. (2014) 2:129. doi: 10.3389/fped.2014.00129

53. Assa’ad AH, Putnam PE, Collins MH, Akers RM, Jameson SC, Kirby CL, et al. Pediatric patients with eosinophilic esophagitis: an 8year follow-up. J Allergy Clin Immunol. (2007) 119:731-8. doi: 10.1016/j.jaci.2006.10.044

54. Rezende ER, Barros CP, Ynoue LH, Santos AT, Pinto RM, Segundo GR. Clinical characteristics and sensitivity to food and inhalants among children with eosinophilic esophagitis. BMC Res Notes (2014) 7:47. doi: 10.1186/1756-0500-7-47

55. Gonsalves N. Distinct features in the clinical presentations of Eosinophilic esophagitis in children and adults: is this the same disease? Dig Dis. (2014) 32:89-92. doi: 10.1159/000357078

56. Furuta AT, Katzka DA. Eosinophilic esophagitis. N Engl J Med. (2015) 373:1640-8. doi: 10.1056/NEJMra1502863

57. Lucendo AJ, Arias A, Molina- Infante J, Rodríguez-Sánchez J, Rodrigo L, Nantes $O$ et al. Diagnostic and therapeutic management of eosinophilic oesophagitis in children and adults: results from a Spanish registry of clinical practice. Dig Liver Dis. (2013) 45:562-8. doi: 10.1016/j.dld.2013.01.013

58. Sperry SL, Crokett SD, Miller CB, Shaheen NJ, Dellon ES. Esophageal foreign-body impactations: epidemiology, time trends, and the impact of the increasing prevalence of eosinophilic esophagitis. Gastrointestinal Endosc. (2011) 74:985-91. doi: 10.1016/j.gie.2011.06.029

59. Straumann A, Aceves SS, Blanchard C, Collins MH, Furuta GT, Hirano I, et al. Pediatric and adult eosinophilic esophagitis: similarities and differences. Allergy (2012) 67:477-90. doi: 10.1111/j.1398-9995.2012.02787.x

60. Remedios M, Jones D, Kerlin P. Eosinophilic oesophagitis: epidemiology, pathogenesis and management. Drugs (2011) 71:527-40. doi: 10.2165/11585450-000000000-00000

61. Lucendo AJ, Sánchez-Castilla M. Adult versus pediatric eosinophilic esophagitis: important differences and similarities for the clinician to understand. Expert Rec Clin Immunol. (2012) 8:733-45. doi: $10.1586 /$ eci. 12.68

62. Pentiuk S, Putnam PE, Collins MH, Rothenberg ME. Dissociation between symptoms and histological severity in pediatric eosinophilic esophagitis. J Pediatr Gastroenterol Nutr. (2009) 48:152-60. doi: 10.1097/MPG.0b013e31817f0197

63. Alexander JA, Jung KW, Arora AS, Enders F, Katzka DA, Kephardt GM, et al. Swallowed fluticasone improves histologic but not symptomatic response of adults with eosinophilic esophagitis. Clin Gastroenterol Hepatol. (2012) 10:742-9. doi: 10.1016/j.cgh.2012.03.018

64. Richter JE. Current management of eosinophilic esophagitis. J Clin Gastroenterol. (2016) 50:99-110. doi: 10.1097/MCG.0000000000000430

65. Lexmond WS, Pardo M, Rooney K, Goettel JA, Snapper SB, Yen EH, et al. Elevated levels of leukotriene C4 synthase mRNA distinguish a subpopulation of eosinophilic esophagitis patients. Clin Exp Allergy (2013) 43:902-13. doi: 10.1111/cea.12146

66. Kim HP, Vance RB, Shaheen NJ, Dellon ES. The prevalence and diagnostic utility of endoscopic features of eosinophilic esophagitis: a meta-analysis. Clin Gastroenterol Hepatol. (2012) 10:988-96. doi: 10.1016/j.cgh.2012.04.019

67. Hirano I, Moy N, Heckman MG, Thomas CS, Gonsalves N, Achem SR. Endoscopic assessment of the oesophageal features of eosinophilic oesophagitis: validation of a novel classification and grading system. Gut (2013) 62:489-95. doi: 10.1136/gutjnl-2011-301817

68. Linz Z, Kahrilas PJ, Xiao Y, Nicodême F, Gonsalves N, Hirano I, et al. Functional luminal imaging probe topography: an improved method for characterizing esophageal distensibility in eosinophilic esophagitis. Ther $A d v$ Gastroenterol. (2013) 6:97-107. doi: 10.1177/1756283X12470017

69. Schlag C, Miehlke S, Heiseke A, Brockow K, Krug A, von Arnim U, et al. Peripheral blood eosinophils and other non-invasive biomarkers can monitor treatment response in eosinophilic oesophagitis. Aliment Pharmacol Ther. (2015) 42:1122-30. doi: 10.1111/apt.13386 
70. Dellon ES, Chen X, Miller CR, Woosley JT, ShaheenNJ. Diagnostic utility of major basic protein, eotaxin-3, and leukotriene enzyme staining in eosinophilic esophagitis. Am J Gastroenterol. (2012) 107:1503-11. doi: 10.1038/ajg.2012.202

71. Dellon ES, Speck O, Woodward K, Covey S, Rusin S, Gebhart JH, et al. Markers of eosinophilic inflammation for diagnosis of eosinophilic esophagitis and proton pump inhibitor-responsive esophageal eosinophilia: a prospective study. Clin Gastroenterol Hepatol. (2014) 12:2015-22. doi: 10.1016/j.cgh.2014.06.019

72. Furuta GT, Kagalwalla AF, Lee JJ, Alumkal P, Maybruck BT, Fillon S, et al. Theoesophageal string test: a novel, minimally invasive method measures mucosal inflammation in eosinophilicoesophagitis. Gut (2013) 62:1395-405. doi: 10.1136/gutjnl-2012-303171

73. Lucendo AJ, Arias A, Tenias JM. Relation between eosinophilic esophagitis and oral immunotherapy for food allergy: a systematic review with meta-analysis. Allergy Asthma Immunol. (2014) 113:624-9. doi: 10.1016/j.anai.2014.08.004

74. Hines BT, Rank MA, Wright BL, Marks LA, Hagan JB, Straumann A, et al. Minimally-invasive biomarker studies in eosinophilic esophagitis: a systematic review. Ann Allergy Asthma Immunol. (2018) 121:218-28. doi: 10.1016/j.anai.2018.05.005

75. Semancik E, Sayej WN. Oral immunotherapy for peanut allergy induces eosinophilic esophagitis: three pediatric case reports. Pediatr Allergy Immunol. (2016) 27:539-41. doi: 10.1111/pai.12554

76. Rodríguez CG, Torrijos EG, De la Pinzón FR, Segade JB, Rodríguez RG, Brito FF, et al. Dysphagia in a boy treated with oral immunotherapy for cow's milk allergy. J Investig Allergol Clin Immunol. (2014) 24:363-5.

77. Gómez Torrijos E, Mendez Díaz Y, Moreno Lozano L, Extremera Ortega AM, Borja Segade J, Feo Brito JF, et al. Frequency and course of eosinophilic esophagitis during oral immunotherapy for cow's milk allergy in a series of 57 children. J Investig Allergol Clin Immunol. (2017) 27:132-133. doi: 10.18176/jiaci.0130

78. Ridolo E, De Angelis GL, Dall'aglio P. Eosinophilic esophagitis after specific oral tolerance induction for egg protein. Ann Allergy Asthma Immunol. (2011) 106:73-4. doi: 10.1016/j.anai.2010.10.010

79. García Rodríguez R, Méndez Díaz Y, Moreno Lozano L, Extremera Ortega A, Gómez Torrijos E. Eosinophilic esophagitis after egg oral immunotherapy in an adult with egg-allergy and egg-bird syndrome. J Investig Allergol Clin Immunol. (2017) 27:266-67. doi: 10.18176/jiaci.0163

80. Miehlke S, Alpan O, Schröder S, Straumann A. Induction of eosinophilic esophagitis by sublingual pollen immunotherapy. Case Rep Gastroenterol. (2013) 7:363-8. doi: 10.1159/000355161

81. Béné J, Ley D, Roboubi R, Gottrand F, Gautier S. Eosinophilic esophagitis after desensitization to dust mites with sublingual immunotherapy. Ann Allergy Asthma Immunol. (2016) 116:583-4. doi: 10.1016/j.anai.2016.0 3.017

82. Gomez Torrijos E, García Rodriguez C, Rodriguez J, De la Roca F, Cárdenas $\mathrm{R}$, Alfaya F, et al. Occupational asthma and eosinophilic esophagitis in a patient with egg-bird syndrome. J Investig Allergol Clin Immunol. (2015) 25:61-2

83. Gomez-Torrijos E, Rodriguez-Sanchez J, Diaz-Perales A, Garcia R, Feo JF, Garcia C, et al. Occupational allergic multiorgan disease. J Allergy Clin Immunol. (2015) 136:1114-6. doi: 10.1016/j.jaci.2015.03.047

84. Molina-Infante J, Bredenoord AJ, ChengE, Dellon ES, Furuta GT, Gupta SK, etal. PPI-REE Task Forceof the European Society of Eosinophilic Oesophagitis (EUREOS). Proton pump inhibitor-responsive oesophageal eosinophilia: an entity challenging current diagnostic criteria for eosinophilic oesophagitis. Gut (2016) 65:524-31. doi: 10.1136/gutjnl-2015-310991

85. Molina-Infante J, Lucendo AJ. Proton pump inhibitor therapy for eosinophilic esophagitis: a paradigm shift. Am J Gastroenterol. (2017) 112:1770-3. doi: 10.1038/ajg.2017.404

86. Menard-Katcher P, Marks KL, Liacouras CA, Spergel JM, Yang YX, Falk GW. The natural history of eosinophilic oesophagitis in the transition from childhood to adulthood. Aliment Pharmacol Ther. (2013) 37:114-21. doi: 10.4172/2155-6121.S8-002

87. Dellon ES, Kim HP, Sperry SL, Rybnicek DA, Woosley JT, Shaheen NJ. A phenotypic analysis shows that eosinophilic esophagitis is a progressive fibrostenotic disease. Gastrointest Endosc. (2014)79:577-85.e4. doi: 10.1016/j.gie.2013.10.027

88. Dellon ES, Hirano I. Epidemiology and natural history of eosinophilic esophagitis. Gastroenterology (2017) 154:319-32.e3. doi: 10.1053/j.gastro.2017.06.067.

89. Straumann A, Spichtin HP, Grize L. Natural history of eosinophilic esophagitis: a follow-up of 30 adult patients for up to 11.4 years. Gastroenterology (2003) 125:1660. doi: 10.1053/j.gastro.2003.09.024

90. Straumann A, Conus S, Degen L, Frei C, Bussmann C, Beglinger C, et al. Long-term budesonide maintenance treatment is partially effective for patients with eosinophilic esophagitis. Clin Gastroenterol Hepatol. (2011) 9:400-9 e1. doi: 10.1016/j.cgh.2011.01.017

91. Nojkov B, Amin M, Ghaith G, Capell MS.A statistically significant association between esophageal granular cell tumors and eosinophilic esophagitis:a 16 year analysis at two large hospitals of 167,434 EGDs. Dig Dis Sci. (2017) 62:3517-24. doi: 10.1007/s10620-017-4802-9

92. Shaheen NJ, Mukkada V, Eichinger CS, Schofield H, Todorova L, Falk GW. Natural history of eosinophilic esophagitis: a systematic review of epidemiology and disease course. Dis Esophagus (2018) 31:1-14. doi: 10.1093/dote/doy015

93. Lucendo AJ, Arias Á, Molina-Infante J. Efficacy of proton pump inhibitor drugs for inducing clinical and histologic remission in patients with symptomatic esophageal eosinophilia: a systematic review and meta analysis. Clin Gastroenterol Hepatol. (2016) 14:13-22.e1. doi: 10.1016/j.cgh.2015.07.041

94. Molina-Infante J, Martinek J, Martinez-Alcala C, Krajciova J, Moawad FJ, Dellon ES. Long-term efficacy of PPI therapy in patients with PPI-responsive esophageal eosinophilia: an International Multicenter Study. Gastroenterology (2014)146(Suppl.1):S-393. doi: 10.1016/S0016-5085(14)60058-5

95. Gutiérrez-Junquera C, Fernández-Fernández S, Cilleruelo ML, Rayo A, Echeverría L, Quevedo S, et al. High prevalence of response to proton pump inhibitor treatment in children with esophageal eosinophilia. J Pediatr Gastroenterol Nutr. (2016) 62:704-10. doi: 10.1097/MPG.0000000000001019

96. Tan ND, Xiao YL, Chen MH. Steroids therapy for eosinophilic esophagitis: systematic review and meta-analysis. J Dig Dis. (2015) 16:431-42. doi: 10.1111/1751-2980.12265

97. Sawas T, Dhalla S, Sayyar M, Pasricha PJ, Hernaez R. Systematic review with meta-analysis: pharmacological interventions for eosinophilic oesophagitis. Aliment Pharmacol Ther. (2015) 41:797-806. doi: 10.1111/apt.13147

98. Chuang MY, Chinnaratha MA, Hancock DG, Woodman R, Wong GR, Cock C, Fraser RJ. Topical steroid therapy for the treatment of eosinophilic esophagitis (EoE): a systematic review and meta-analysis. Clin Transl Gastroenterol. (2015) 6:e82.

99. Gupta SK, Vitanza JM, Collins MH. Efficacy and safety of oral budesonide suspension in pediatric patients with eosinophilic esophagitis. Clin Gastroenterol Hepatol. (2015) 13:66-76. doi: 10.1016/j.cgh.2014.05.021

100. Dellon ES, Sheikh A, Speck O, Woodward K, Whitlow AB, Hores JM, et al. Viscous topical is more effective than nebulized steroid therapy for patients with eosinophilic esophagitis. Gastroenterology (2012) 143:321-4. doi: 10.1053/j.gastro.2012.04.049

101. Kuchen T, Straumann A, Safroneeva E, Romero Y, Bussmann C, Vavricka $\mathrm{S}$, et al. Swallowed topical corticosteroids reduce the risk for long-lasting bolus impactions in eosinophilic esophagitis. Allergy (2014) 69:1248-54. doi: 10.1111/all.12455

102. Papodopoulou A, Koletzko S, Heuschkel R, Dias JA, Allen KJ, Murch SH, et al. Management guidelines of eosinophilic esophagitis in childhood. J Pediatr Gastroenterol Nutr. (2014) 58:107-18. doi: 10.1097/MPG.0b013e3182a80be1

103. Butz BK, Wen T, Gleich GJ, Furuta GT, Spergel J, King E, et al. Efficacy, dose reduction, and resistance to high-dose fluticasone in patients with eosinophilic esophagitis.Gastroenterology (2014) 147:324-33. doi: 10.1053/j.gastro.2014.04.019

104. Schroeder S, Fleischer DM, Masterson JC, Gelfand E, Furuta GT, Atkins D. Successful treatment of eosinophilic esophagitis with ciclesonide. J Allergy Clin Immunol. (2012) 129:1419-21. doi: 10.1016/j.jaci.2012. 03.007 
105. Lee JJ, Fried AJ, Hait E, Yen EH, Perkins JM, Rubinstein E. Topical inhaled ciclesonide for treatment of eosinophilic esophagitis. Allergy Clin Immunol. (2012) 130:1011 doi: 10.1016/j.jaci.2012.06.053

106. Dohil R, Newbury R, Fox L, Bastian J, Aceves S. Oral viscous budesonide is effective in children with eosinophilic esophagitis in a randomized, placebocontrolled trial. Gastroenterology (2010) 139:418-29. doi: 10.1053/j.gastro.2010.05.001

107. Tomizawa Y, Melek J, Sakuraba A. Comparison of efficacy of pharmacologic therapy of eosinophilic esophagitis (EoE): a systematic review and network meta-analysis. Gastroenterology (2015) 148(4 Suppl. 1): S-792. doi: 10.1016/S0016-5085(15)32706-2

108. Bussmann C, von Arnim U, Bajbouj M, Schlag C, Madisch A, Fibbe C, et al. A randomised, double-blind trial comparing budesonide formulations and dosages for short-term treatment of eosinophilic oesophagitis. Gut (2016) 65:390-9. doi: 10.1136/gutjnl-2014-308815

109. Wolf WA, Cotton CC, Green DJ, Hughes JT, Woosley JT, Shaheen NJ, et al. Predictors of response to steroid therapy for eosinophilic esophagitis and treatment of steroid-refractory patients. Clin Gastroenterol Hepatol. (2015) 13:452-8. doi: 10.1016/j.cgh.2014.07.034

110. Albert D, Heifert T, Min S, Maydonovitch C, Baker TP, Chen YJ, et al. Comparisons of fluticasone to budesonide in the treatment of eosinophilic esophagitis. Dig Dis Sci. (2016) 61:1996-2001. doi: 10.1007/s10620-016-4110-9

111. Philla KQ, Min SB, Hefner JN, Howard RS, Reinhardt BJ, Nazareno LG, et al. Swallowed glucocorticoid therapy for eosinophilic esophagitis in children does not suppress adrenal function. J Pediatr Endocrinol Metab. (2015) 28:1101-6. doi: 10.1515/jpem-2014-0260

112. Harel S, Hursh BE, Chan ES, Avinashi V, Panagiotopoulos C. Adrenal suppression in children treated with oral viscous budesonide for eosinophilic esophagitis: a pilot study. J Pediatr Gastroenterol Nutr. (2015) 61:190-3. doi: 10.1097/MPG.0000000000000848

113. Molina-Infante J, Lucendo AJ. Update on topical steroid therapy for eosinophilic esophagitis. Gastroenterol Hepatol. (2015) 38:388-97. doi: 10.1016/j.gastrohep.2014.12.006

114. Schaefer ET, Fitzgerald JF, Molleston JP, Croffie JM, Pfefferkorn MD, Corkins $\mathrm{MR}$, et al. Comparison of oral prednisone and topical fluticasone in the treatment of eosinophilic esophagitis: a randomized trial in children. Clin Gastroenterol Hepatol. (2008) 6: 165-73. doi: 10.1016/j.cgh.2007.11.008

115. Elliott EJ, Thomas D, Markowitz JE. Non-surgical interventions for eosinophilic esophagitis (Review). Cochrane Database Syst Rev. (2010) CD004065. doi: 10.1002/14651858.CD004065.pub3

116. Molina-Infante J, Gonzalez-Cordero PL, Arias A, Lucendo AJ. Update on dietary therapy for eosinophilic esophagitis in children and adults. Expert Rev Gastroenterol Hepatol. (2017)11:115-23. doi: 10.1080/17474124.2017.1271324

117. McQuaid KR, Laine L. A systematic review and meta-analysis of randomized, controlled trials of moderate sedation for routine endoscopic procedures. Gastrointest Endosc. (2008) 67:910-23. doi: 10.1016/j.gie.2007.12.046

118. Molina-Infante J, Arias A, Vara-Brenes D, Prados-Manzano R, GonzalezCervera J, Alvarado-Arenas M, et al. Propofol administration is safe in adult eosinophilic esophagitis patients sensitized to egg, soy, or peanut. Allergy (2014) 69:388-94. doi: 10.1111/all.12360

119. Higuera Pulgar I, Bretón Lesmes I, Carrascal Fabián ML, Prieto García A, Menchén Viso L, Nogales Rincón Ó, et al. Ingesta dietética de pacientes adultos con esofagitis eosinofílica que siguen una dieta de exclusión de seis grupos de alimentos. Nutr Hosp. (2016) 33:387. doi: 10.20960/nh.387

120. Kelly KJ, Lazenby AJ, Rowe PC, Yardley JH, Perman JA, Sampson HA. Eosinophilic esophagitis attributed to gastroesophageal reflux: improvement with an aminoacid-based formula. Gastroenterology (1995) 109:1503-12. doi: 10.1016/0016-5085(95)90637-1

121. Liacouras CA, Spergel JM, Ruchelli E, Verma R, Mascarenhas M, Semeao E, et al. Eosinophilic esophagitis: a 10-year experience in 381 children. Clin Gastroenterol Hepatol. (2005) 3:1198-206. doi: 10.1016/S1542-3565(05)00885-2

122. Markowitz JE, Spergel JM, Ruchelli E, Liacouras CA. Elemental diet is an effective treatment for eosinophilic esophagitis in children and adolescents. Am J Gastroenterol. (2003) 98:777-82. doi: 10.1111/j.1572-0241.2003. 07390.x
123. Henderson CJ, Abonia JP, King EC, Putnam PE, Collins MH, Franciosi JP, et al. Comparative dietary therapy effectiveness in remission of pediatric eosinophilic esophagitis. J Allergy Clin Immunol. (2012) 129:1570-8. doi: $10.1016 /$ j.jaci.2012.03.023

124. Spergel JM, Brown-Whitehorn TF, Cianferoni A, Shuker M, Wang ML, Verma R, et al. Identification of causative foods in children with eosinophilic esophagitis treated with an elimination diet. J Allergy Clin Immunol. (2012)130:461-7. doi: 10.1016/j.jaci.2012.05.021

125. Peterson KA, Byrne KR, Vinson LA, Ying J, Boynton KK, Fang JC, et al. Elemental diet induces histologic response in adult eosinophilic esophagitis. Am J Gastroenterol. (2013) 108:759-66. doi: 10.1038/ajg.2012.468

126. Spergel JM, Beausoleil JL, Mascarenhas M, Liacouras CA. The use of skin prick tests and patch tests to identify causative foods in eosinophilic esophagitis. J Allergy Clin Immunol. (2002) 109:363-8. doi: $10.1067 /$ mai.2002.121458

127. Spergel JM, Andrews T, Brown-Whitehorn TF, Beausoleil JL, Liacouras C. Treatment of eosinophilic esophagitis with specific food elimination diet directed by a combination of skin prick and patch tests. Ann Allergy Asthma Immunol. (2005) 95:336-43. doi: 10.1016/S1081-1206(10)61151-9

128. Molina-Infante J, Martin-Noguerol E, Alvarado-Arenas M, PorcelCarreño SL, Jimenez-Timon S, Hernandez-Arbeiza FJ. Selective elimination diet based on skin testing has suboptimal efficacy for adult eosinophilic esophagitis. J Allergy Clin Immunol. (2012) 130:1200-2. doi: 10.1016/j.jaci.2012.06.027

129. Rizo Pascual JM, De La Hoz Caballer B, Redondo Verge C, Terrados cepeda S, Roy Ariño G, Riesco Lopez JM et al. Allergy assessment in children with eosinophilic esophagitis. J Investig Allergol Clin Immunol. (2011) 21:59-65.

130. Al-Hussaini A, Al-Idressi E, Al-Zahrani M. The role of allergy evaluation in children with eosinophilic esophagitis. J Gastroenterol. (2013) 48:1205-12. doi: 10.1007/s00535-012-0741-6

131. Simon D, Straumann A, Wenk A, Spichtin H, Simon H-U, Braathen LR. Eosinophilic esophagitis in adults-no clinical relevance of wheat and rye sensitizations. Allergy (2006) 61:1480-3. doi: 10.1111/j.1398-9995.2006.01224.x

132. Arias A, González-Cervera J, Tenias JM, Lucendo AJ. Efficacy of dietary interventions for inducing histologic remission in patients with eosinophilic esophagitis: a systematic review and meta-analysis. Gastroenterology (2014)146:1639-48. doi: 10.1053/j.gastro.2014.02.006

133. Rodríguez-Sánchez J, Gómez Torrijos E, López Viedma B, de la Santa Belda E, Martín Dávila F, García Rodríguez C et al. Efficacy of IgE-targeted vs empiric six-food elimination diets for adult eosinophilic oesophagitis. Allergy (2014) 69:936-42. doi: 10.1111/all.12420

134. Van Rhijn BD, Vlieg-Boerstra BJ, Versteeg SA, Akkerdaas JH, van Ree R, Terreehorst I, et al. Evaluation of allergen-microarray-guided dietary intervention as treatment of eosinophilic esophagitis. $J$ Allergy Clin Immunol. (2015) 136:1095-7. doi: 10.1016/j.jaci.2015.0 2.038

135. Lucendo AJ, Arias Á, González-Cervera J, Yagüe-Compadre JL, Guagnozzi D, Angueira T, et al. Empiric 6-food elimination diet induced and maintained prolonged remission in patients with adult eosinophilic esophagitis: a prospective study on the food cause of the disease. J Allergy Clin Immunol. (2013) 131:797-804. doi: 10.1016/j.jaci.2012.12.664

136. Kagalwalla AF, Sentongo TA, Ritz S, Hess T, Nelson SP, Emerick KM, et al. Effect of six-food elimination diet on clinical and histologic outcomes in eosinophilic esophagitis. Clin Gastroenterol Hepatol. (2006) 4:1097-102. doi: 10.1016/j.cgh.2006.05.026

137. Kagalwalla AF, Shah A, Li BU, Sentongo TA, Ritz S, Manuel-Rubio $M$, et al. Identification of specific foods responsible for inflammation in children with eosinophilic esophagitis successfully treated with empiric elimination diet. J Pediatr Gastroenterol Nutr. (2011) 53:145-9. doi: 10.1097/MPG.0b013e31821cf503

138. Gonsalves N, Yang G-Y, Doerfler B, Ritz S, Ditto AM, Hirano I. Elimination diet effectively treats eosinophilic esophagitis in adults; food reintroduction identifies causative factors. Gastroenterology (2012) 142:1451-9. doi: 10.1053/j.gastro.2012.03.001

139. Gonsalves N, Doerfler B, Hirano I. Long term maintenance therapy with dietary restriction in adults with eosinophilic esophagitis. Gastroenterology (2011) 140 (5, Suppl. 1):S180-1. doi: 10.1016/S0016-5085(11)60729-4 
140. Arias Á, Lucendo AJ. Dietary therapies for eosinophilic esophagitis. Expert Rev Clin Immunol. (2014) 10:133-42. doi: 10.1016/j.jaci.2018.02.028

141. Molina-Infante J, Arias A, Barrio J, Rodríguez-Sánchez J, SanchezCazalilla M, Lucendo AJ. Four-food group elimination diet for adult eosinophilic esophagitis: a prospective multicenter study. J Allergy Clin Immunol. (2014) 134:1093-9. doi: 10.1016/j.jaci.2014.07.023

142. Kagalwalla A, Amsden K, Makhija MM, Wechsler JB, Davis CM, Johnson $\mathrm{K}$, et al. A multicenter study assessing the clinical, endoscopic and histologic response to four food elimination diet for the treatment of eosinophilic esophagitis. Gastroenterology (2015) 148(Suppl. 1):S-30. doi: 10.1016/S0016-5085(15)30103-7

143. Kagalwalla AF, Amsden K, Shah A, Ritz S, Manuel-Rubio M, Dunne $\mathrm{K}$, et al. Cow's milk elimination : a novel dietary approach to treat eosinophilic esophagitis. J Pediatr Gastroenterol Nutr. (2012)55:711-6. doi: 10.1097/MPG.0b013e318268da40

144. Kruszewski PG, Russo JM, Franciosi JP, Varni JW, Platts-Mills TA, Erwin EA. Prospective, comparative effectiveness trial of cow's milk elimination and swallowed fluticasone for pediatric eosinophilic esophagitis. Dis Esophagus (2016) 29:377-84. doi: 10.1111/dote.12339

145. Lucendo AJ, Arias Á, González-Cervera J, Mota-Huertas T, YagüeCompadre JL. Tolerance of a cow's milk-based hydrolyzed formula in patients with eosinophilic esophagitis triggered by milk. Allergy (2013) 68:1065-72. doi: $10.1111 /$ all.12200

146. Leung J, Hundal NV, Katz AJ, Shreffler WG, Yuan Q, Butterworth CA, et al. Tolerance of baked milk in patients with cow's milk-mediated eosinophilic esophagitis. J Allergy Clin Immunol. (2013) 132:1215-6. doi: 10.1016/j.jaci.2013.08.017

147. Nhu QM, Aceves SS. Medical and dietary management of eosinophilic esophagitis. Ann Allergy Asthma Immunol. (2018) 121:156-61. doi: 10.1016/j.anai.2018.05.006

148. Lucendo AJ, De Rezende LC, Jiménez-Contreras S, Yagüe-Compadre JL, González-Cervera J, Mota-Huertas T, et al. Montelukast was inefficient in maintaining steroid-induced remission in adult eosinophilic esophagitis. Dig Dis Sci. (2011) 56:3551-8. doi: 10.1007/s10620-011-1775-y

149. Spergel JM, Rothemberg ME, Collins MH, Furuta GT, Markowitz JE, Fuchs G, et al. Reslizumab in children and adolescents with eosinophilic esophagitis: results of a double-blind, randomized, placebo-controlled trial. J Allergy Clin Immunol. (2012) 129:456-463. doi: 10.1016/j.jaci.2011. 11.044

150. Straumann A, Conus S, Grzonka P, Kita H, Kephart G, Bussmann C, et al. Antiinterleukin-5 antibody treatment (mepolizumab) in active eosinophilic oesophagitis: a randomised, placebo-controlled, double-blind trial. Gut (2010) 59:21-30. doi: 10.1136/gut.2009.178558

151. Straumann A, Bussmann C, Conus S, Beglinger C, Simon HU. AntiTNFalpha (infliximab) therapy for severe adult eosinophilic esophagitis. J Allergy Clin Immunol. (2008) 122:425-7. doi: 10.1016/j.jaci.2008.06.012

152. Clayton F, Fang JC, Gleich GJ, Lucendo AJ, Olalla JM, Vinson LA, et al. Eosinophilic esophagitis in adults is associated with IgG4 and not mediated by IgE. Gastroenterology (2014) 147:602-9. doi: 10.1053/j.gastro.2014. 05.036
153. Rocha R, Vitor AB, Trindale E, Lima R, Tavares M, Lopes J, et al. Omalizumab in the treatment of eosinophilic esophagitis and food allergy. Eur J Pediatr. (2011)170:1471-4. doi: 10.1007/s00431-011-1540-4

154. Loizou D, Enav B, Komlodi-Pasztor E, Hider P, Kim-Chang J, Noonan L, et al. A pilot study of omalizumab in eosinophilic esophagitis. PLoS ONE (2015) 10:e0113483. doi: 10.1371/journal.pone.0113483

155. Straumann A, Hoesli S, BussmannCh, Stuck M, Perkins M, Collins LP, et al. Anti-eosinophil activity and clinical efficacy of the CRTH2 antagonist OC000459 in eosinophilic esophagitis. Allergy (2013) 68:375-85. doi: 10.1111/all.12096

156. Karo-Atar D, Bitton A, Benhar I, Munitz A. Therapeutic targeting of the interleukin-4/interleukin-13 signaling pathway: in allergy and beyond. BioDrugs (2018). doi: 10.1007/s40259-018-0280-7. [Epub ahead of print].

157. Rothenberg ME, Wen $\mathrm{T}$, Greenberg A, Alpan O, Enav B, Hirano I, et al. Intravenous anti IL-13 mAb QAX576 for the treatment of eosinophilic esophagitis. J Allergy Clin Immunol. (2015) 135:500-7. doi: 10.1016/j.jaci.2014.07.049

158. Straumann A. Eosinophilic esophagitis emerging therapies and future perspectives. Gastroenterol Clin North Am. (2014) 43:385-94. doi: 10.1016/j.gtc.2014.02.005

159. Netzer P, Gschossmann JM, Straumann A, Sendensky A, Weimann R, Schoepfer AM. Corticosteroid-dependent eosinophilic oesophagitis: azathioprine and 6-mercaptapurine can induce and maintain longterm remission. Eur J Gastroenterol Hepatol. (2007) 19:865-9. doi: 10.1097/MEG.0b013e32825a6ab4

160. Manka LA, Wechsler ME. New biologics for allergic diseases. Expert Rev Clin Immunol. (2018) 14:285-96. doi: 10.1080/1744666X.2018.1459188

161. Moawad FJ, Cheatham JG, DeZee KJ. Meta-analysis: the safety and efficacy of dilation in eosinophilic oesophagitis. Aliment Pharmacol Ther. (2013)38:713-20. doi: 10.1111/apt.12438

162. Jacobs JV, Spechler SJ. A systematic review of the risk of perforation during esophageal dilation for patients eosinophilic esophagitis. Dig Dis Sci. (2010) 55:1512-5. doi: 10.1007/s10620-010-1165-x

163. Schoepfer A, Blanchard C, Dawson H, Lucendo A, Mauro A, Ribi C, et al. Eosinophilic esophagitis: latest insights from diagnosis to therapy. Ann N Y Acad Sci. (2018). doi: 10.1111/nyas.13731. [Epub ahead of print].

Conflict of Interest Statement: The authors declare that the research was conducted in the absence of any commercial or financial relationships that could be construed as a potential conflict of interest.

Copyright (๑) 2018 Gomez Torrijos, Gonzalez-Mendiola, Alvarado, Avila, PrietoGarcia, Valbuena, Borja, Infante, Lopez, Marchan, Prieto, Moro, Rosado, Saiz, Somoza, Uriel, Vazquez, Mur, Poza-Guedes and Bartra. This is an open-access article distributed under the terms of the Creative Commons Attribution License (CC BY). The use, distribution or reproduction in other forums is permitted, provided the original author(s) and the copyright owner(s) are credited and that the original publication in this journal is cited, in accordance with accepted academic practice. No use, distribution or reproduction is permitted which does not comply with these terms. 